\title{
Review of seed yield components and pollination conditions in red clover (Trifolium pratense L.) seed production
}

\author{
Shuxuan Jing $(\mathbb{D} \cdot$ Per Kryger $(\mathbb{D} \cdot$ Birte Boelt $\mathbb{D}$
}

Received: 4 January 2021 / Accepted: 1 March 2021 / Published online: 25 March 2021

(C) The Author(s) 2021

\begin{abstract}
Red clover (Trifolium pratense L.) is an important forage legume grown in many of the temperate regions around the world. In order to evaluate possible causes for the low seed yield in particular in tetraploid red clover, we surveyed 71 studies of red clover seed production published from 1948 to 2019, reviewing seed yield components, pollination and reproductive traits. Seed yield components are recorded to contribute to and improve our understanding of the complex processes leading to the red clover seed yield. However, the measurement approaches varied largely among the studies, depending on whether the seed yield components are directly measured or calculated. Red clover seed production is dependent on insect pollen transfer. However, much uncertainty of pollination and reproductive success remains. Pollination conditions were often neglected: one third of the papers did not mention pollination conditions. The information that connects pollination and seed set are lacking, very few studies measured traits in floral morphology, ovule fertilisation and seed maturation. We suggest that consistent and comprehensive evaluation of pollination and reproductive
\end{abstract}

Supplementary Information The online version contains supplementary material available at https://doi.org/10.1007/ s10681-021-02793-0.

S. Jing $\cdot$ P. Kryger $\cdot$ B. Boelt $(\bowtie)$

Department of Agroecology, Faculty of Technical Sciences, Aarhus University, 4200 Slagelse, Denmark e-mail: bb@agro.au.dk success are required to improve our understanding of reasons for the low seed yield in red clover and hence the possibilities for future improvement.

Keywords Red clover - Seed production - Seed yield components · Plant reproduction · Pollination .

Pollinator

\section{Introduction}

Red clover (Trifolium pratense L.) is an important forage legume with a long cultivation history, being grown in many temperate regions of the world (Taylor and Quesenberry 1996; Boller et al. 2010). High forage yield and persistence have been the main breeding goals (Boller et al. 2010; Boelt et al. 2015). However, intensive selections make it a challenge to combine high vegetative qualities and high, stable seed yield in one cultivar; thus seed growers' acceptance of red clover is limited in spite of the high forage yield (Hides and Desroches 1990; Taylor and Quesenberry 1996; Elgersma and Van Wijk 1998; Boller et al. 2010).

Both the seed yield and the seed production area of red clover have been declining during the last decades. Bommarco et al. (2012) reported a declining seed yield with a doubled variation in seed yield in Sweden and suggested that the reasons might be the lack of 
pollination and the introduction of tetraploid red clover. The natural ploidy level of red clover is diploid $(2 \mathrm{n}=2 \mathrm{x}=14)$, while tetraploids $(2 \mathrm{n}=4 \mathrm{x}=28)$ can be bred by doubling the chromosomes sets, using both asexual (e.g., colchicine) or sexual ( $2 \mathrm{n}$ gametes) methods (Annicchiarico et al. 2015). Usually a seed yield of 400 to $600 \mathrm{~kg} \mathrm{ha}^{-1}$ can be expected with the seeding rate of $10 \mathrm{~kg} \mathrm{ha}^{-1}$ (Boller et al. 2010). However, seed yield of tetraploids is $20-50 \%$ lower than diploids in spite of a higher forage yield (Boller et al. 2010). Another reason for the decreasing red clover seed production might be the increased use of white clover (Trifolium repens L.) as a forage crop (Taylor and Quesenberry 1996; Boller et al. 2010). In Denmark, the seed production area was around 500 ha for red clover and 2500 ha for white clover in 1997 (Burgon et al. 1997). In 2019, the 10-year average was 292 ha for red clover and 3520 ha for white clover seed production (The Danish Seed Council 2020).

Red clover is more drought tolerant than white clover. Red clover develops a strong taproot from the primary seedling root, whereas the taproot of white clover is replaced by shallow roots during the first production year (Annicchiarico et al. 2015). Future climatic conditions with increased drought-stress is expected to increase the interest in using deep-rooting legume species such as red clover in grassland mixtures (Lüscher et al. 2014). Red clover seed yield is of importance for its market success, but the actual seed yield often represents a mere fraction of the theoretical seed yield, indicating an underused exploitation potential (Dennis and Haas 1967; Boller et al. 2010).

Seed yield is a complex trait. Analysing seed yield components contributes to the understanding of the processes influencing the seed yield. Also, seed yield components reflect the differences between the potential and the realized seed yield (Boelt and Studer 2010). Potential seed yield can be calculated before harvest to examine the influencing factors for the seed loss, such as inadequate pollination, reduced floral fertility, irregularities in seed development, and seed loss during harvest management (Forster and Hadfield 1958; Hampton 1990; Oliva et al. 1994; Taylor and Quesenberry 1996). The calculation of potential seed yield requires the information of different seed yield components such as seed weight, seed number per floret, floret number per flower head, and flower head number per unit area (Oliva et al. 1994). For seed growers and large-scale field production, seed yield is usually expressed in seed weight per unit area, e.g. kilogram per hectare $\left(\mathrm{kg} \mathrm{ha}^{-1}\right)$ (Taylor and Quesenberry 1996; Amdahl et al. 2016). In plant breeding research, seed yield is often expressed as seed yield (g) per flower head (e.g., Herrmann et al. 2006; Amdahl et al. 2017), seed yield (g) per plant (e.g., Herrmann et al. 2006; Vleugels et al. 2016, 2019b; Amdahl et al. 2017) and seed number per plant (e.g., Vleugels et al. 2015), depending if the study objects were single plants or large-scale field trials. Recent studies have sought to determine the most important seed yield components to characterize red clover seed yield and they suggested that seed number per flower head and flower head number per plant are the most important seed yield components for seed yield per plant (Herrmann et al. 2006; Vleugels et al. 2015, 2016, 2019a; Amdahl et al. 2017). However, these studies differed in methods estimating seed yield based on measured or calculated seed yield components. While two of these studies directly measured seed number per flower head, flower head number per plant and seed yield per plant (i.e., Herrmann et al. 2006; Amdahl et al. 2017), other papers used calculated or partly calculated seed yield components. Currently, there is a lack of uniformity in measuring seed yield components and for some seed yield components original data are scarce. Inconsistency in the recording of seed yield components and the lack of original data for some components limit the possibilities to untangle reasons for the low red clover seed yield - whether during breeding of new cultivars or seed production management.

Diploid red clover is allogamous with a strong selfincompatibility system determined by a single S-locus: it requires cross-pollination to produce seed (Taylor and Quesenberry 1996; Urda and Savatti 2008). Nevertheless, high self-pollination rate was found in some tetraploid genotypes, probably due to the intensive selection for high seed-yielding tetraploids (Vleugels et al. 2019c). Large-scale red clover seed production relies on insect pollinators, in particular bumble bees (Bombus spp.) and honey bees (Apis mellifera L.) (Free 1993). As a reward for the pollination service, bees gather nectar and pollen from red clover as carbohydrate and protein sources (Free 1993). Pollination success is often directly measured as stigmatic pollen deposition and indirectly by pollinator abundance, visit frequency and duration of 
the visit (Ne'eman et al. 2010). Previous studies proposed that bumble bees are more efficient pollinators compared to honey bees due to their higher visit frequency, longer working hours and higher tolerance to the adverse weather conditions (Westgate and Coe 1915; Starling et al. 1950; Peterson et al. 1960). The shortened corolla tube length of red clover florets was regarded as a floral trait to improve pollinator attractiveness because some honey bee subspecies are not able to reach the base of corolla tubes to access the nectar (Dennis and Holm 1977). A recent study reviewed the corolla hypothesis and suggested that, while it may be valid in some specific cases, the corolla hypothesis should not be generalised, due to the large variation in pollinator species and subspecies in different regions (Vleugels et al. 2019a). In general, the attractiveness of forage legumes for pollinators and the floret fertility seems to be overlooked in breeding programs (Boelt et al. 2015).

Honey bees can be supplementary or alternative pollination approach for red clover seed production. Placing five colonies of honey bees per hectare was recommended (Rincker and Rampton 1985; Taylor and Quesenberry 1996; Brødsgaard and Hansen 2002; Rao and Stephen 2009). However, general recommendations may not accurately apply to the pollination requirement for different seed production fields (Garibaldi et al. 2020). The extent to which insectpollinated crops depends on honey bees is difficult to estimate, since for certain crops the areas grown, exceed what can be covered by honey bees alone (Breeze et al. 2011). Wermuth and Dupont (2010) detected no influence of added honey bee hives did to the red clover seed yield under field conditions in Denmark, whereas Walstrom (1958) found that red clover seed yield decreased when the distance to the honey bee colonies increased above $122 \mathrm{~m}$. Moreover, the use of honey bee hives are limited due to bee diseases, the colony collapse disorder and high renting costs (Rao and Stephen 2009, 2010). Therefore, monitoring pollination conditions in seed production fields is important for improving crop pollination management. Also, the information of pollination conditions is critical for linking seed growers and beekeepers, because both red and white clover are commonly visited crops for beekeepers in Europe (Breeze et al. 2019), as their flowers are favoured by honey bees (Baude et al. 2016).
In addition to pollination success, the reproduction of an angiosperm plant is influenced by the stages of flower determination, ovary development before flowering and seed development and maturation after pollination (Lloyd 1980). The flower determination stage can be investigated by measuring floret numbers and flower head numbers.

The objective of the current study is to review the red clover seed production studies published during the last decades by investigating (1) to what extent seed yield components were described and analysed; (2) to what extent the information on pollination and reproductive success was provided.

\section{Methods}

We first sought the topic (i.e., title, abstract, author keywords, and Keywords Plus) in Web of Science. 753 studies were presented by using 'red clover* seed' in June, 2019. An extra search was conducted in March, 2020 , by using 'trifolium pratense* seed', with 501 studies presented. We examined the titles and abstracts and selected the studies that had the aim of improving red clover seed yield. Reviews and research studies that had the aim of improving vegetative qualities and seed qualities were excluded. Studies that were without available online sources or not written in English were also excluded. During the time of writing (March, 2020), 67 studies published from 1948 to 2019 were identified that met the criteria. During the revising (February, 2021), we manually included additional four studies. In total 71 studies published from 1948 to 2019 were included in this review (Appendix A). We examined each study by extracting information of the individual seed yield component (Table 1). We only included directly registered/ measured seed yield components and excluded calculated seed yield components. We defined classification levels of pollination condition (Table 2). Additionally, we examined the number of papers reporting ovule fertilization, seed maturation and seed germination. 
Table 1 Description of the individual registered seed yield components (Photos: C.H. Knudsen \& S. Jing)

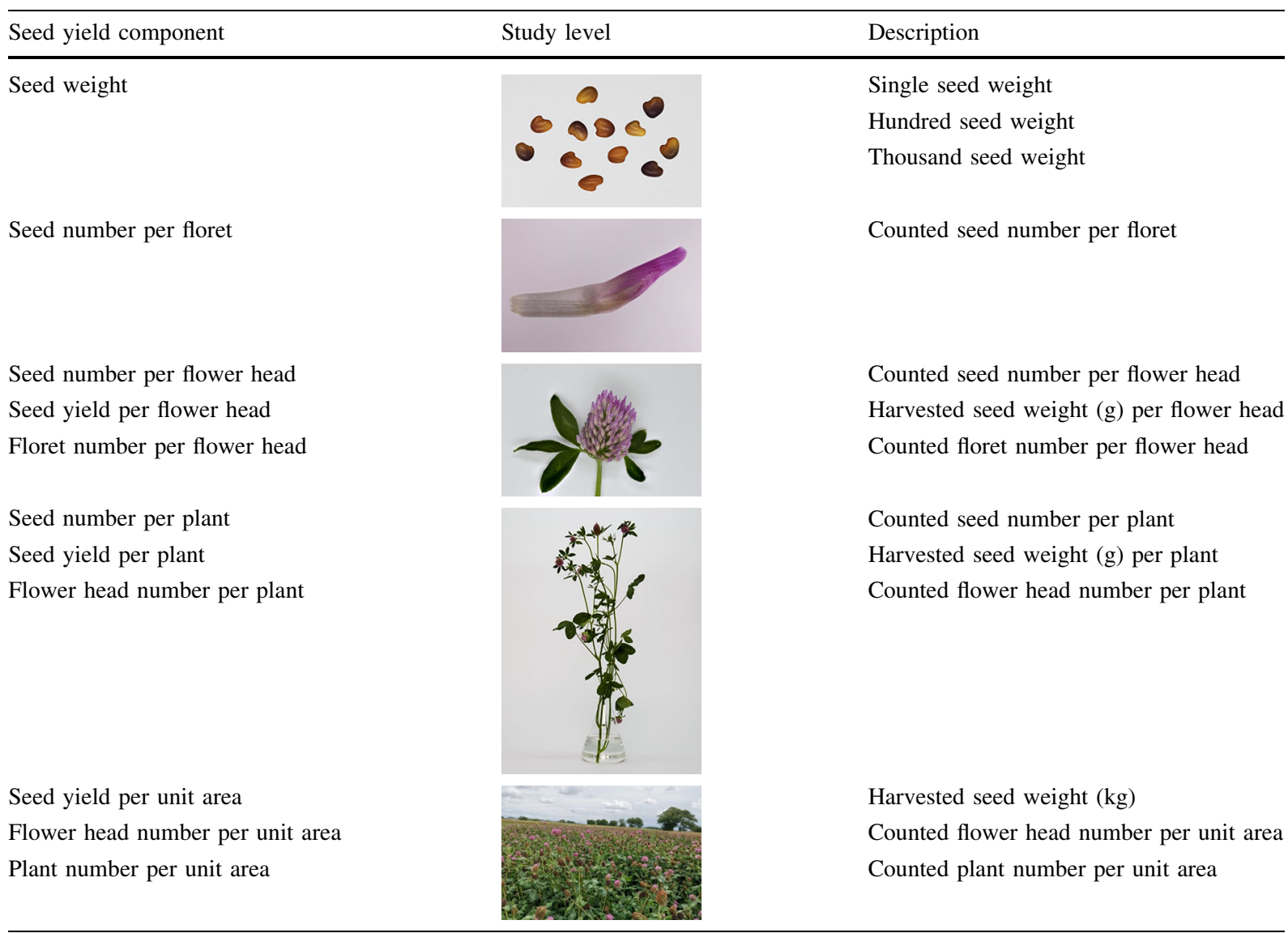

\section{Results and discussion}

\section{Seed yield components}

The number of surveyed papers that reported individual seed yield components at different study levels (i.e., seed, floret, flower head, plant, and unit area) are shown in Fig. 1. More than half of the surveyed studies (38 papers) reported the seed yield per unit area. There were fewer papers that reported the seed yield at the plant level (15 papers) or flower head level (10 papers). Compared with measuring seed yield components at dense canopy level, it is more practical and less laborious to measure the seed yield components at single plant level (Amdahl et al. 2017). The information of seed yield components is important in plant breeding programmes to evaluate and understand the seed yield differences among different red clover populations (Amdahl et al. 2017), and suggest factors for improvement. Our review illustrates that there are different approaches to estimate the final seed yield using the information of individual seed yield components at different study levels (Fig. 1). Among the different approaches, we found that the simplest way to calculate the seed yield per unit area is by multiplying flower head number per unit area and seed yield per flower head (Fig. 1). These two seed yield components, were previously suggested as the two most important seed yield components in determining seed yield per unit area (Oliva et al. 1994; Steiner et al. 1997; Amdahl et al. 2016; Vleugels et al. 2019a). However, seed yield per flower head is the product of seed weight, the number of florets per flower head and the number of seeds per floret, where the latter is a reflection of the pollination and the reproductive success. Seed yield is measured at 
Table 2 Classification of the information level of pollination condition, pollination success and floral trait

\begin{tabular}{|c|c|c|}
\hline Classification type & Information level & Description \\
\hline \multirow{5}{*}{$\begin{array}{l}\text { Pollination } \\
\text { condition }\end{array}$} & No mention & Pollination condition not mentioned \\
\hline & Little mention & Pollinators mentioned without specifying species or only in the discussion part \\
\hline & Quantifying honey bee hives & Number of honey bee hives quantified \\
\hline & $\begin{array}{l}\text { Quantifying bumble bee } \\
\text { species }\end{array}$ & Number of bumble bee species quantified \\
\hline & Hand pollination & Studies conducted using hand pollination approach \\
\hline \multirow[t]{3}{*}{ Pollination success } & Stigmatic pollen deposition & Number of pollen grains deposited on the stigma quantified \\
\hline & Visit frequency & Number of florets visited per unit time (e.g., per minute) quantified \\
\hline & Abundance & Number of individuals per unit area for each pollinator species quantified \\
\hline \multirow[t]{6}{*}{ Floral trait } & Corolla tube length & Corolla tube length measured \\
\hline & Corolla tube diameter & Corolla tube diameter measured \\
\hline & Nectar volume & $\begin{array}{l}\text { Measured directly from the red clover plants or indirectly from the honey bee } \\
\text { hives }\end{array}$ \\
\hline & Sugar concentration & Measured from the red clover plants \\
\hline & Pollen quantity & $\begin{array}{l}\text { Measured directly from red clover plants or indirectly from the honey bee } \\
\text { hives }\end{array}$ \\
\hline & Pollen quality & Pollen quality related to conspecificity, viability, and compatibility measured \\
\hline
\end{tabular}

Floret number $(24) *$

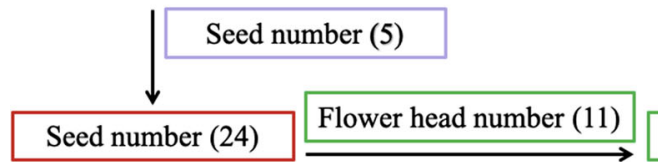

Seed number (4)

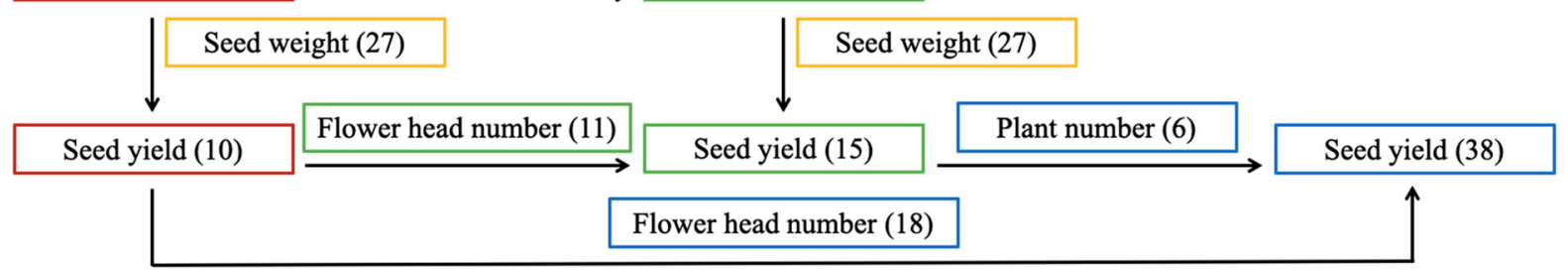

Fig. 1 Seed yield components in 71 surveyed papers and the number of papers (in parentheses) that registered/measured the individual seed yield component. *Seed yield components with different colours of frame indicate different study levels (e.g.,

harvest with the purpose of illustrating how seed yield components influence the final seed yield (Hampton and Fairey 1997). For instance, the loss of flower heads over the season and the loss of seeds during the harvest process will result in a reduced final seed yield, compared to the potential seed yield (Oliva et al. 1994). Therefore, it is relevant to know how and when each individual seed yield component was measured,
'Floret number' with the red frame means floret number per flower head). Arrows indicate different approaches to estimating seed yield components

in order to minimize the discrepancy between studies. We will focus the following discussions on flower head numbers and seed yield per flower head and their correlated seed yield components.

Flower head numbers can be measured at different times and at the level of per-shoot, per-plant, or perunit area (Hampton and Fairey 1997). More than a third (26 papers) of the surveyed papers reported 
flower head numbers, of which 11 papers reported flower head number per plant and 18 papers reported flower head number per unit area (three papers reported both). We also attempted to investigate the time the flower head number were counted in the surveyed papers. Among the 25 papers that investigated the flower head number, 14 papers measured this trait at the time of peak flowering while 14 papers measured at the time of harvest. Six papers measured the flower head number both at the time of peak flowering and at the time of harvest. It may be assumed that measuring flower head numbers at seed harvest time can better predict the final seed yield. Contrastingly, Steiner et al. (1995) found that flower head numbers of red clover at the harvest time were poorly correlated with the final seed yield and argued that the contribution of flower head numbers required knowledge of both adequate time and soil moisture for the seed maturation. For example, red clover flower head numbers were affected by water stress, but seed number per floret was found the most influential seed yield component that affected the seed yield (Oliva et al. 1994). Management practices of irrigation, the use of plant growth regulator such as daminozide (Alar-85) and trinexapac-ethyl, and forage removal may improve the number of flower heads, and the depending factors/limitations have been well discussed in the previous studies (Puri and Laidlaw 1983; Christie and Choo 1990; Oliva et al. 1994; Steiner et al. 1995; Taylor and Quesenberry 1996; Anderson et al. 2016).

Seed yield per flower head can be measured directly (10 papers) or can be calculated through seed number per flower head (24 papers) and seed weight (27 papers) as shown in Fig. 1. Seed number per flower head has been used for a long time as an indicator to determine whether the red clover crop is worth saving for seeds, and the number of 25 seeds per flower head was suggested as a standard (Richmond 1932; Taylor and Quesenberry 1996). Nevertheless, there is a lack of information on whether this standard should be updated with the development of current red clover cultivation and seed production practices. Thousand seed weight is a traditional way to express seed weight due to its relative constancy, and light and small seeds may be eliminated during the cleaning process (Hampton and Hebblethwaite 1983; Hampton and Fairey 1997). In the current study, $38 \%$ of the investigated papers reported seed weight, within which half measured thousand seed weight.

Both floret number per flower head and seed number per floret contribute to the seed number per flower head (Fig. 1). Theoretically, each red clover floret has the potential to produce two seeds because it contains one ovary with two ovules, but usually florets only produce one seed (Lorenzetti 1993; Taylor and Quesenberry 1996). One third (24 papers) of the 71 surveyed papers reported the floret number per flower head. However, currently we are lacking information about the seed number per floret, because only five out of the 71 surveyed papers reported the seed number produced per floret by checking the individual floret and counting the seed number produced per floret (Fig. 1). This may be due to the tedious task of determining seed numbers per floret. Evaluation of the pollination success in red clover is currently hampered by the lack of information of the number of florets per flower head producing zero, one or two seeds. Instead of checking each floret directly, seed numbers per floret are often calculated and presented as averaged numbers for a plant or shoot (Hampton and Fairey 1997), obscuring the variation. We found that 19 surveyed papers calculated the seed number per floret based on the information of seed number and floret number, but this was described with five different terminologies: seed set, fertility, seeds per floret, florets with seed, floret site utilization (Table 3). Some of these five terminologies were also used to describe other measured seed yield components (Table 3), which makes the information among the studies confusing. We also investigated whether the studies shown in Table 3 had included considerations of each floret having the potential to produce two seeds per floret. Only seven papers had mentioned or had included information of individual floret having two ovules per ovary and potentially producing two seeds. Seeds from two-seeded florets have lower seed weights than seeds from one-seeded florets in red clover (Dijkstra 1969). Nevertheless, whether the ability to produce two seeds per floret may influence the seed yield and seed quality is still unclarified. Dijkstra (1969) found no correlation between twoseededness and seed yield and speculated that the reason could be the lack of measuring flower head numbers. The fertility between a red clover flower head that produces ten seeds from ten one-seeded florets is different from a flower head that produces ten 
Table 3 Overview of various terms describing measured seed yield components

\begin{tabular}{|c|c|c|c|}
\hline $\begin{array}{l}\text { Measured seed yield } \\
\text { component }\end{array}$ & Unit & Term used & References \\
\hline \multirow[t]{5}{*}{$\begin{array}{l}\text { Seed number per } \\
\text { pollinated floret number }\end{array}$} & \multirow[t]{5}{*}{$\%$} & Seed set & $\begin{array}{l}\text { Battle (1949), Free (1965), Pankiw et al. (1977), Puri and Laidlaw (1983), Puri } \\
\text { and Laidlaw (1984), Leduc (1990), Rao and Stephen (2009), Lundin et al. } \\
\text { (2013), Herrmann et al. (2006), Mihovsky and Naydenova (2018) and } \\
\text { Vleugelset al. (2019c) }\end{array}$ \\
\hline & & Fertility & Amdahl et al. (2017), Kovi et al. (2017) and Tomić et al. (2014, 2015) \\
\hline & & $\begin{array}{l}\text { Seeds per } \\
\text { floret }\end{array}$ & Dade (1966) and Anderson et al. (2016) \\
\hline & & $\begin{array}{l}\text { Florets with } \\
\text { seed }\end{array}$ & Woodrow et al. (1952) and Palmer-Jones et al. (1966) \\
\hline & & $\begin{array}{l}\text { Floret site } \\
\text { utilization }\end{array}$ & Anderson et al. (2016) \\
\hline \multirow[t]{2}{*}{$\begin{array}{l}\text { Seed number per pod of } \\
\text { the floret }\end{array}$} & \multirow[t]{2}{*}{ Seed } & $\begin{array}{l}\text { Seeds per } \\
\text { pod }\end{array}$ & Dijkstra (1969) and Richards (2016) \\
\hline & & $\begin{array}{l}\text { Seeds per } \\
\text { floret }\end{array}$ & Oliva et al. (1994) \\
\hline $\begin{array}{l}\text { Seed number per flower } \\
\text { head }\end{array}$ & Seed & Seed set & Hawkins (1961), Clifford and Scott (1989) and Gillespie et al. (2015) \\
\hline $\begin{array}{l}\text { Seed yield per flower } \\
\text { head }\end{array}$ & $\mathrm{g}$ & Fertility & Meglic and Smith (1992) \\
\hline
\end{tabular}

seeds from five two-seeded florets. Therefore, increasing our understanding of red clover fertility requires more detailed information about the pollination success and the reproductive success on a per floret level. Based on differences in calculations, terminologies, and considerations of two-seeded florets, it is very difficult to compare the seed number per floret among different studies. We suggest future studies to specify the definitions of seed number per floret and to use the terminology seed set, which is defined as the percentage of ovules that developed into seeds (Ne'eman et al. 2010). Although ovule site utilization might be a more precise terminology used to describe the percentage of ovules developed to seeds in red clover (Lorenzetti 1993), none of the surveyed studies used the terminology ovule site utilization while 11 of the surveyed studies used the terminology seed set (Table 3). The calculation of seed set should be based on the fact that there are two ovules per floret (potentially two seeds). Moreover, harvest and cleaning process should be taken into consideration (Elgersma 1991). Seed number per floret reflects pollination conditions. The lack of original data describing this particular seed yield component hampers the possibility to evaluate pollination and reproductive success and to identify potential ways for improvement-whether during plant breeding or seed production management.

Pollination conditions

Information levels of pollination conditions and pollination success were surveyed in 71 red clover seed production papers (Table 4). Surprisingly, one third (24 papers) of the surveyed papers did not mention pollination conditions. Less than one third of the papers specified and quantified the set-up of honey bee hives and/or specified the bumble bee species in the studies. Vleugels et al. (2019a) suggest that pollination cannot explain seed yield differences in red clover in relation to genotypes or ploidy levels. We sought the information of the pollination conditions and pollination success within the 36 papers that had specified bumble bee species and/or honey bee hives. More than one third (14 papers) recorded the abundance of pollinators. While only five papers correlated the seed set with the bee visitation (i.e., Forster and Hadfield 1958; Free 1965; Palmer-Jones et al. 1966; Clifford and Scott 1989; Lundin et al. 2013). None of 
Table 4 Number of papers demonstrating pollination conditions with different information levels

\begin{tabular}{ll}
\hline Information level of pollination & No. papers \\
\hline No mention & 24 \\
Little mention $^{\dagger}$ & 8 \\
Quantifying honey bee hives & 20 \\
Quantifying bumble bee species & 23 \\
Hand pollination & 3 \\
\hline
\end{tabular}

The totals exceed the number of 71 surveyed paper as 7 papers specified both honey bee hives and bumble bee species

'LLittle mention' includes the number of papers mentioning pollinators but without specifying pollinators species, and includes the number of papers only mentioning pollination in the discussion

the studies measured the stigmatic pollen deposition in red clover, indicating limited information at the floret level. Due to the generally poor information level of pollination in the studies we surveyed, more research and specific evidence are needed to clarify the role of pollination on seed yield in red clover.

In the surveyed papers, floral morphology was not well investigated. Approximately $11 \%$ of the papers measured corolla tube traits, and fewer than $10 \%$ of the surveyed studies measured floral traits such as nectar and pollen production. Increasing nectar production was one suggested breeding target to attract more pollinators (Vanommeslaeghe et al. 2018). Nevertheless, the difficulties in measuring floral traits of nectar and pollen might be the limiting factor. Shuel (1952) demonstrated the difficulty of breeding red clover with higher nectar volume and sugar concentration due to various influencing environmental factors such as temperature, humidity, soil moisture, photoperiod as well as light intensity. Furthermore, red clover pollen viability was found to be influenced by the weather conditions (Vleugels et al. 2019a).

Fabaceae plants and especially red clover are major pollen and nectar sources for most bumble bee species (Goulson et al. 2005; Bommarco et al. 2012). Rundlöf et al. (2014) suggested that late-flowering red clover increases bumble bee reproduction. Our study indicates that there is a knowledge gap between the research areas of seed production and the ecosystem service of insect pollination. Quantification studies of species-specific pollination activities are needed for improving red clover pollination and seed production.
Future studies can be conducted by answering questions from different perspectives, for example: how many flower resources are needed for pollinator conservation and how many visits of honey bees are enough for red clover seed production (Goodwin et al. 2011; Dicks et al. 2015). Methods and management practices for monitoring pollinators and improving pollination conditions have been updated. For example, the abundance of pollinators can be potentially recorded and distinguished by using the portable timelapse video camera and a high-resolution laser-radar system (Edwards et al. 2015; Kirkeby et al. 2016). DNA metabarcoding and a pollen-tracking method using quantum dots as pollen labels can be potential methods to identify plant-pollinator interactions (Macgregor et al. 2018; Minnaar and Anderson 2019). According to Baude et al. (2016), historical changes of floral resources can be estimated by combining quantified nectar measurements and vegetation surveys. The use of annual flower strips was found supporting bumble bee species richness in red clover fields (Rundlöf et al. 2018).

As red clover is a cross-pollinated crop, we should take pollination into consideration when we want to improve seed yield both in the breeding of new cultivars and in seed production management. For example, if we increase the number of flower heads per plant at the field scale, the plants may attract more pollinators to the field by providing more pollen and nectar sources for pollinators. Furthermore, seed number and seed weight were saturated at low pollen loads on the stigma in oilseed rape (Brassica napus L.), indicating that low pollen amounts may be sufficient for seed production (Lankinen et al. 2018). A hand pollination study showed that high pollen quality, measured as pollen viability, is more important than the amount of pollen deposited on the stigma for red clover seed production (Jing et al. 2019).

Ovule fertilisation and seed development

The processes of ovule fertilisation and seed development play important roles in linking the pollination success and plant reproductive success. However, we found fewer than $10 \%$ (6 papers) of the studies that recorded the ovule fertilisation and seed maturation, indicating scarceness of investigations. Studying ovule, embryo and seed development further our understanding at several levels: (1) the causes for the 
lower fertility in tetraploids compared to diploids (Julén 1950; Vleugels et al. 2019a, b, c ); (2) the selfincompatibility system (Leduc et al. 1990; Vleugels et al. 2019c); (3) the quality of pollen transfer (Rao and Stephen 2009; Richards 2016); (4) the evaluation of pest damage to seeds (Johansen 1960). There is a necessity to connect pollination and reproductive success in future studies. For example, pollen tube growth from pollinator visits can be measured to connect to ovule fertilisation and seed development (Stavert et al. 2020). Also, we found 20\% (14 papers) of the studies reported seed germination, lower than the number of studies reported seed weight (27 papers). Sometimes viable seeds may not be able to germinate because of seed dormancy and environmental conditions during harvest and storage (Hampton and Hill 2002; Petkovic et al. 2017). In addition to the improvement of forage yield, obtaining high seed yields are critical in plant breeding programmes (Hampton and Hill 2002; Boelt et al. 2015). Future breeding activities may benefit from more emphasis on evaluating reproductive traits.

\section{Conclusions}

Seed yield components, pollination and reproductive success traits are interrelated and influence the red clover seed yield. Previous studies indicated that the seed yield components of flower head numbers and seed yield per flower head play major roles in red clover seed production. However, the varied approaches to record the seed yield components (direct measurements or calculations) may cause contrasting results among the studies. Direct studies that link pollination success and reproductive success are lacking. First, few (5 papers) reported seed number per floret, a seed yield component that is directly connected to pollination and reproductive success. Second, pollination conditions have been poorly described. The variations in pollinator species, pollination management (i.e., the use of honey bee hives) and floral morphology may result in differences when comparing among studies. Last, only a few (8 papers) investigated ovule fertilisation and seed maturation. Further studies that relate pollination and fertility traits are needed to quantify the role of pollination and reproductive success in seed production of red clover.
Authors' contributions B. Boelt, P. Kryger, S. Jing conceptualized the article; S. Jing performed the literature search, data analysis and prepared the draft; B. Boelt and P. Kryger revised and edited the work.

Funding This work was supported by GUDP (Grønt Udviklings- og Demonstrationsprogram) Project Number 34009-13-0726, the Danish Agricultural Agency under the Ministry of Environment and Food of Denmark.

Conflict of interest The authors declare that the research was conducted in the absence of any commercial or financial relationships that could be construed as a potential conflict of interest.

Open Access This article is licensed under a Creative Commons Attribution 4.0 International License, which permits use, sharing, adaptation, distribution and reproduction in any medium or format, as long as you give appropriate credit to the original author(s) and the source, provide a link to the Creative Commons licence, and indicate if changes were made. The images or other third party material in this article are included in the article's Creative Commons licence, unless indicated otherwise in a credit line to the material. If material is not included in the article's Creative Commons licence and your intended use is not permitted by statutory regulation or exceeds the permitted use, you will need to obtain permission directly from the copyright holder. To view a copy of this licence, visit http://creativecommons.org/licenses/by/4.0/.

\section{References}

Amdahl H, Aamlid TS, Ergon Å, Kovi MR, Marum P, Alsheikh M, Rognli OA (2016) Seed yield of Norwegian and Swedish tetraploid red clover (Trifolium pratense L.) populations. Crop Sci 56:603-612. https://doi.org/10. 2135/cropsci2015.07.0441

Amdahl H, Aamlid TS, Marum P, Ergon Å, Alsheikh M, Rognli OA (2017) Seed yield components in single plants of diverse Scandinavian tetraploid red clover populations (Trifolium pratense L.). Crop Sci 57:108-117. https://doi. org/10.2135/cropsci2016.05.0321

Anderson NP, Chastain TG, Garbacik CJ (2016) Irrigation and trinexapac-ethyl effects on seed yield in first-and secondyear red clover stands. Agron J 108:1116-1123. https://doi. org/10.2134/agronj2015.0513

Annicchiarico P, Barrett B, Brummer EC, Julier B, Marshall AH (2015) Achievements and challenges in improving temperate perennial forage legumes. CRC Crit Rev Plant Sci 34:327-380. https://doi.org/10.1080/07352689.2014. 898462

Battle W (1949) Seed production on excised red clover stems. Agron J 41:141-143. https://doi.org/10.2134/agronj1949. $00021962004100040002 x$

Baude M, Kunin WE, Boatman ND, Conyers S, Davies N, Gillespie MAK, Morton RD, Smart SM, Memmott J (2016) Historical nectar assessment reveals the fall and rise of 
floral resources in Britain. Nature 530:85-88. https://doi. org/10.1038/nature 16532

Boelt B, Julier B, Karagić Đ, Hampton J (2015) Legume seed production meeting market requirements and economic impacts. CRC Crit Rev Plant Sci 34:412-427. https://doi. org/10.1080/07352689.2014.898477

Boelt B, Studer B (2010) Breeding for grass seed yield. In: Boller B, Posselt UK, Veronesi F (eds) Fodder crops and amenity grasses, handbook of plant breeding, vol 5 . Springer, New York, pp 161-174

Boller B, Schubiger FX, Kölliker R (2010) Red clover. In: Boller B, Posselt UK, Veronesi F (eds) Fodder crops and amenity grasses, handbook of plant breeding, vol 5 . Springer, New York, pp 439-455

Bommarco R, Lundin O, Smith HG, Rundlöf M (2012) Drastic historic shifts in bumble-bee community composition in Sweden. Proc R Soc B 279:309-315. https://doi.org/10. 1098/rspb.2011.0647

Breeze TD, Bailey AP, Balcombe KG, Potts SG (2011) Pollination services in the UK: how important are honeybees? Agric Ecosyst Environ 142:137-143. https://doi.org/10. 1016/j.agee.2011.03.020

Breeze TD, Boreux V, Cole L, Dicks L, Klein A, Pufal G, Balzan MV, Bevk D, Bortolotti L, Petanidou T, Mand M, Pinto MA, Scheper J, Stanisavljević L, Stavrinides MC, Tscheulin T, Varnava A, Kleijn D (2019) Linking farmer and beekeeper preferences with ecological knowledge to improve crop pollination. People Nat 1:562-572. https:// doi.org/10.1002/pan3.10055

Brødsgaard CJ, Hansen H (2002) Pollination of red clover in Denmark. DIAS report Plant Production no. 71. Danish Institute of Agricultural Sciences, Tjele.

Burgon A, Bondeson OB, Verburgt WH, Hall AG, Bark NS, Robinson M, Timm G (1997) The forage seed trade. In: Fairey DT, Hampton JG (eds) Forage seed production, vol I. Temperate species. CAB International, Wallingford, pp 271-286

Christie BR, Choo TM (1990) Effects of harvest time and Alar85 on seed yield of red clover. Can J Plant Sci 70:869-871. https://doi.org/10.4141/cjps90-106

Clifford PTP, Scott D (1989) Inflorescence, bumble bee, and climate interactions in seed crops of a tetraploid red clover (Trifolium pratense L.). J Appl Seed Prod 7:38-45

Dade E (1966) Effects of clipping on red clover seed yields and seed-yield components. Crop Sci 6:348-350. https://doi. org/10.2135/cropsci1966.0011183X000600040016x

Dennis BA, Haas H (1967) Pollination and seed-setting in diploid and tetraploid Red clover (Trifolium pratense L.) under Danish conditions II. Studies of floret morphology in relation to the working speed of honey and bumble bees (Hymenoptera Apoidea). Den Aarsskr Kgl Vet \& Landbohojsk 118-133.

Dennis B, Holm SN (1977) Recent trends in red clover pollination. Pszczel Zeszyty Nauk 21:149-157

Dicks LV, Baude M, Roberts SPM, Phillips J, Green M, Carvell C (2015) How much flower-rich habitat is enough for wild pollinators? Answering a key policy question with incomplete knowledge: Flower-rich habitat for pollinators. Ecol Entomol 40:22-35. https://doi.org/10.1111/een. 12226
Dijkstra J (1969) The importance of two-seeded pods in red clover (Trifolium pratense L.). Euphytica 18:340-351. https://doi.org/10.1007/BF00397781

Edwards J, Smith GP, McEntee MHF (2015) Long-term timelapse video provides near complete records of floral visitation. J Pollinat Ecol 16:91-100. https://doi.org/10.26786/ $1920-7603 \% 282015 \% 2916$

Elgersma A (1991) Floret size utilisation in perennial ryegrass (Lolium perenne L.). J Appl Seed Prod 9:38-43

Elgersma A, Van Wijk AJP (1998) Breeding for higher seed yields in grasses and legumes. In: Fairey DT, Hampton JG (eds) Forage seed production, vol I. Temperate species. CAB International, Wallingford, pp 243-270

Forster IW, Hadfield WV (1958) Effectiveness of honey bees and bumble bees in the pollination of Montgomery red clover. New Zealand J Agric Res 1:607-619. https://doi. org/10.1080/00288233.1958.10431568

Free JB (1965) The ability of bumblebees and honeybees to pollinate red clover. J Appl Ecol 2:289-294. https://doi. org/10.2307/2401480

Free JB (1993) Insect pollination of crops. Academic Press, London

Garibaldi LA, Sáez A, Aizen MA, Fijen T, Bartomeus I (2020) Crop pollination management needs flower-visitor monitoring and target values. J Appl Ecol 57:664-670. https:// doi.org/10.1111/1365-2664.13574

Gillespie SD, Carrero K, Adler LS (2015) Relationships between parasitism, bumblebee foraging behaviour, and pollination service to Trifolium pratense flowers. Ecol Entomol 40:650-653. https://doi.org/10.1111/een.12236

Goodwin RM, Cox HM, Taylor MA, Evans LJ, McBrydie HM (2011) Number of honey bee visits required to fully pollinate white clover (Trifolium repens) seed crops in Canterbury, New Zealand. N Z J Crop Hortic Sci 39:7-19. https://doi.org/10.1080/01140671.2010.520164

Goulson D, Hanley ME, Darvill B, Ellis JS, Knight ME (2005) Causes of rarity in bumblebees. Biol Conserv 122:1-8. https://doi.org/10.1016/j.biocon.2004.06.017

Hampton JG (1990) Genetic variability and climatic factors affecting herbage legume seed production: an introduction. J Appl Seed Prod 8:45-51

Hampton JG, Fairey DT (1997) Components of seed yield in grasses and legumes. In: Fairey DT, Hampton JG (eds) Forage seed production, vol I. Temperate species. CAB International, Wallingford, pp 45-69

Hampton JG, Hebblethwaite PD (1983) Yield components of the perennial ryegrass (Lolium perenne L.) seed crop. J Appl Seed Prod 1:23-25

Hampton JG, Hill MJ (2002) Seed quality and New Zealand's native plants: an unexplored relationship? $\mathrm{N} \mathrm{Z} \mathrm{J}$ Bot 40:357-364

Hawkins RP (1961) Observations on the pollination of red clover by bees. Ann Appl Biol 49:55-65. https://doi.org/ 10.1111/j.1744-7348.1961.tb03592.x

Herrmann D, Boller B, Studer B, Widmer F, Kölliker R (2006) QTL analysis of seed yield components in red clover (Trifolium pratense L.). Theor Appl Genet 112:536-545. https://doi.org/10.1007/s00122-005-0158-1

Hides DH, Desroches R (1990) The role of seeds in forage production-factors limiting optimal utilization. In: 
Proceedings of the XVI international grassland congress, pp 1777-1784.

Jing S, Kryger P, Boelt B (2019) Is red clover seed set potential influenced by pollen quality? In: Proceedings of the 10th international herbage seed conference, pp 51-54.

Johansen C (1960) Bee poisoning versus clover aphid control in red clover grown for seed. J Econ Entomol 53:1012-1015. https://doi.org/10.1093/jee/53.6.1012

Julén U (1950) Fertility conditions of tetraploid red clover. Hereditas 36:151-160. https://doi.org/10.1111/j.16015223.1950.tb03369.x

Kirkeby C, Wellenreuther M, Brydegaard M (2016) Observations of movement dynamics of flying insects using high resolution lidar. Sci Rep 6:29083. https://doi.org/10.1038/ srep29083

Kovi MR, Amdahl H, Alsheikh M, Rognli OA (2017) De novo and reference transcriptome assembly of transcripts expressed during flowering provide insight into seed setting in tetraploid red clover. Sci Rep 7:44383. https://doi. org/10.1038/srep44383

Lankinen Å, Lindström SAM, D'Hertefeldt T (2018) Variable pollen viability and effects of pollen load size on components of seed set in cultivars and feral populations of oilseed rape. PLoS ONE 13:e0204407. https://doi.org/10. 1371/journal.pone.0204407

Leduc N, Douglas GC, Monnier M, Connolly V (1990) Pollination in vitro: effects on the growth of pollen tubes, seed set and gametophytic self-incompatibility in Trifolium pratense $\mathrm{L}$. and $T$. repens $\mathrm{L}$. Theor Appl Genet 80:657-664. https://doi.org/10.1007/bf00224226

Lloyd DG (1980) Sexual strategies in plants: I. An hypothesis of serial adjustment of maternal investment during one reproductive session. New Phytol 86:69-79. https://doi. org/10.1111/j.1469-8137.1980.tb00780.x

Lorenzetti F (1993) Achieving potential herbage seed yields in species of temperate regions. In: Proceedings of the XVII international grassland congress, pp 1621-1628

Lundin O, Smith HG, Rundlöf M, Bommarco R (2013) When ecosystem services interact: crop pollination benefits depend on the level of pest control. Proc R Soc B 280:20122243. https://doi.org/10.1098/rspb.2012.2243

Lüscher A, Mueller-Harvey I, Soussana JF, Rees RM, Peyraud JL (2014) Potential of legume-based grassland-livestock systems in Europe: a review. Grass Forage Sci 69:206-228. https://doi.org/10.1111/gfs.12124

Macgregor CJ, Kitson JJN, Fox R, Hahn C, Lunt DH, Pocock MJO, Evans DM (2018) Construction, validation, and application of nocturnal pollen transport networks in an agro-ecosystem: a comparison using light microscopy and DNA metabarcoding. Ecol Entomol 44:17-29. https://doi. org/10.1111/een. 12674

Meglic V, Smith RR (1992) Self-incompatibility and seed set in colchicine-, nitrous oxide-, and sexually derived tetraploid red clover. Crop Sci 32:1133-1137. https://doi.org/10. 2135/cropsci1992.0011183X003200050013x

Mihovsky T, Naydenova G (2018) Phenotypic analysis and heritability of seed production components in red clover (Trifolium pratense L.). Bulg J Agric Sci 24:46-49

Minnaar C, Anderson B (2019) Using quantum dots as pollen labels to track the fates of individual pollen grains.
Methods Ecol Evol 10:604-614. https://doi.org/10.1111/ 2041-210X.13155

Ne'eman G, Jürgens A, Newstrom-Lloyd L, Potts SG, Dafni A (2010) A framework for comparing pollinator performance: Effectiveness and efficiency. Biol Rev 85:435-451. https://doi.org/10.1111/j.1469-185X.2009.00108.x

Oliva RN, Steiner JJ, Young WC (1994) Red clover seed production: II. Plant water status on yield and yield components. Crop Sci 34:184-192. https://doi.org/10.2135/ cropsci1994.0011183X003400010033x

Palmer-Jones T, Forster IW, Clinch PG (1966) Observations on the pollination of Montgomery red clover (Trifolium pratense L.). New Zealand J Agric Res 9:738-747. https://doi. org/10.1080/00288233.1966.10431563

Pankiw P, Bonin S, Lieverse J (1977) Effects of row spacing and seeding rates on seed yield in red clover, alsike clover and birdsfoot trefoil. Can J Plant Sci 57:413-418. https://doi. org/10.4141/cjps77-060

Peterson AG, Furgala B, Holdaway FG (1960) Pollination of red clover in Minnesota. J Econ Entomol 53:546-550. https:// doi.org/10.1093/jee/53.4.546

Petkovic B, Przulj N, Radić V, Mirosavljević M (2017) Comparative study of seed yield and seed quality of advanced lines and commercial varieties of red clover (Trifolium pratense L.). Legume Res 40:1066-1071. https://doi.org/ 10.18805/LR-360

Puri KP, Laidlaw AS (1983) The effect of cutting in spring and application of Alar on red clover (Trifolium pratense L.) seed production. J Appl Seed Prod 1:12-18

Puri KP, Laidlaw AS (1984) The effect of time of harvest on seed production of three red clover cultivars. Grass Forage Sci 39:221-228. https://doi.org/10.1111/j.1365-2494. 1984.tb01686.x

Rao S, Stephen WP (2009) Bumble bee pollinators in red clover seed production. Crop Sci 49:2207-2214. https://doi.org/ 10.2135/cropsci2009.01.0003

Rao S, Stephen WP (2010) Abundance and diversity of native bumble bees associated with agricultural crops: the Willamette Valley experience. Psyche 2010:1-9. https://doi. org/10.1155/2010/354072

Richards KW (2016) Effectiveness of the alfalfa leafcutter bee Megachile rotundata Fab. to pollinate perennial clovers. J Apic Res 55:259-267. https://doi.org/10.1080/00218839. 2016.1225865

Richmond RG (1932) Red clover pollination by honeybees in Colorado. https://mountainscholar.org/bitstream/handle/ 10217/6240/COAB_82376199.pdf?sequence=1. Accessed 29 June 2020

Rincker CM, Rampton HH (1985) Seed production. In: Taylor NL (ed) Clover science and technology. American Society of Agronomy Inc, Madison, pp 417-443

Rundlöf M, Persson AS, Smith HG, Bommarco R (2014) Lateseason mass-flowering red clover increases bumble bee queen and male densities. Biol Conserv 172:138-145. https://doi.org/10.1016/j.biocon.2014.02.027

Rundlöf M, Lundin O, Bommarco R (2018) Annual flower strips support pollinators and potentially enhance red clover seed yield. Ecol Evol 8:7974-7985. https://doi.org/10.1002/ ece 3.4330 
Shuel RW (1952) Some factors affecting nectar secretion in red clover. Plant Physiol 27:95. https://doi.org/10.1104/pp.27. 1.95

Starling TM, Wilsie CP, Gilbert NW (1950) Corolla tube length studies in red clover. Agron J 42:1-8. https://doi.org/10. 2134/agronj1950.00021962004200010001x

Stavert JR, Bailey C, Kirkland L, Rader R (2020) Pollen tube growth from multiple pollinator visits more accurately quantifies pollinator performance and plant reproduction. Sci Rep 10:16958. https://doi.org/10.1038/s41598-02073637-5

Steiner JJ, Leffel JA, Gingrich G, Aldrich-Markham S (1995) Red clover seed production: III. Effect of forage removal time under varied environments. Crop Sci 35:1667-1675. https://doi.org/10.2135/cropsci1995. 0011183X003500060026x

Steiner JJ, Smith RR, Alderman SC (1997) Red clover seed production: IV. Root rot resistance under forage and seed production systems. Crop Sci 37:1278-1282. https://doi. org/10.2135/cropsci1997.0011183X003700040042x

Taylor NL, Quesenberry KH (1996) Red clover science. Kluwer Academic Publisher, Dordrecht

The Danish Seed Council, 2020. Årsberetning 2019. https://lf. dk/om-os/om-landbrug-og-foedevarer/vores-medlemmer/ brancher/brancheudvalget-for-froe/aarsberetninger/. Accessed 29 June 2020

Tomić D, Stevović V, Đurović D, Stanisavljević R (2014) Effect of cobalt application on seed production in red clover (Trifolium pratense L.). J Agric Sci Technol 16:517-526

Tomić D, Stevović V, Đurović D, Madić M, Bokan N, Stanisavljević R (2015) Boron application in red clover (Trifolium pratense L.) seed production. Irish J Agric Food Res 54:59-63. https://doi.org/10.1515/ijafr-2015-0006

Urda M, Savatti M (2008) Pollination and binding seeds process on di-and tetraploid red clover (Trifolium pratense L.) in Transylvania's conditions. Res J Agric Sci 40:335-340

Vanommeslaeghe A, Meeus I, Cnops G, Vleugels T, Merchiers M, Duquenne B, Roldán-Ruiz I, Smagghe G (2018) Influence of pollinator abundance and flower visitation on seed yield in red clover. Arthropod-Plant Interact 12:339-349. https://doi.org/10.1007/s11829-017-9593-6
Vleugels T, Amdahl H, Roldán-Ruiz I, Cnops G (2019a) Factors underlying seed yield in red clover: review of current knowledge and perspectives. Agronomy 9:829. https://doi. org/10.3390/agronomy9120829

Vleugels T, Ceuppens B, Cnops G, Lootens P, van Parijs FRD, Smagghe G, Roldán-Ruiz I (2016) Models with only two predictor variables can accurately predict seed yield in diploid and tetraploid red clover. Euphytica 209:507-523. https://doi.org/10.1007/s10681-016-1679-1

Vleugels T, Roldán-Ruiz I, Cnops G (2015) Influence of flower and flowering characteristics on seed yield in diploid and tetraploid red clover. Plant Breed 134:56-61. https://doi. org/10.1111/pbr.12224

Vleugels T, Roldán-Ruiz I, Cnops G (2019b) Marker-assisted parentage analysis reveals high individual selfing rates in tetraploid red clover genotypes selected for seed yield. Plant Breed 138:947-957. https://doi.org/10.1111/pbr. 12741

Vleugels T, Van Laere K, Roldán-Ruiz I, Cnops G (2019c) Seed yield in red clover is associated with meiotic abnormalities and in tetraploid genotypes also with self-compatibility. Euphytica 215:79. https://doi.org/10.1007/s10681-0192405-6

Walstrom R (1958) Effects of flight distances from honey bee colonies on red clover seed yields. J Econ Entomol 51:64-67. https://doi.org/10.1093/jee/51.1.64

Wermuth KH, Dupont YL (2010) Effects of field characteristics on abundance of bumblebees (Bombus spp.) and seed yield in red clover fields. Apidologie 41:657-666. https://doi. org/10.1051/apido/2010038

Westgate JM, Coe HS (1915) Red clover seed production studies. Bull US Dep Agric 289:31

Woodrow AW (1952) Effect of time of pollination by honey bees on red clover seed yields. J Econ Entomol 45:517-519. https://doi.org/10.1093/jee/45.3.517

Publisher's Note Springer Nature remains neutral with regard to jurisdictional claims in published maps and institutional affiliations. 